\title{
PERUBAHAN PENGGUNAAN RUANG KOTA DAN BANGUNAN PADA KAWASAN BUDAYA OLEH PERKEMBANGAN TEKNOLOGI DALAM KONSTRUKSI DAN UPAYA REVITALISASI
}

\author{
Agus S Sadana* \\ Jurusan Arsitektur Universitas Pancasila, Jakarta \\ *sadana_m15@yahoo.com
}

\begin{abstract}
ABSTRAK
Upaya pelestarian dan konservasi bangunan kuno pada kawasan budaya hingga saat ini masih menemui nanyak kendala. Perubahan struktur kota yang kurang terkendali sebagai akibat dari pesatnya perkembangan perekonomian mempunyai andil yang cukup besar dalam tersingkirkannya kawasan budaya di sebagian kota-kota besar. Semakin banyaknya kebutuhan luas ruang dalam bangunan pada lahan yang sama telah mendorong public dan arsitek untuk memaksimalkan penggunaan lahan. Perkembangan perekonomian yang pesat juga mendorong public untuk mencari image-image baru sebagai identitas kemajuan itu sendiri. Selanjutnya, kehadiran teknologi modern masa kini dalam dunia konstruksi juga semakin mempermudah public dan arsitek mewujudkan image-image baru tersebut ke dalam sosok bangunan. Masih lemahnya perhatian pada pelestarian serta lemahnya pengawasan pada penggunaan lahan perkotaan mendorong terjadinya perubahan pola tata ruang kawasan dan bangunan yang nyaris tak terkendali. Akibatnya, di sebagian kawasan budaya sering munculnya sosok bangunan baru tanpa identitas yang jelas, terjadi perubahan bahkan pemusnahan pada bangunan-bangunan lama yang menjadi penanda kawasan tersebut, atau terjadi perpindahan aktivitas ke dalam kawasan dan sosok bangunan baru di luar kawasan pusat kota lama. Akibatnya, pusat kota lama mulai kehilangan identitasnya, atau perlahan-lahan menjadi kawasan mati karena ditinggalkan penghuninya. Perkembangan yang demikian ini bertolak belakang dengan cita-cita dan nilai-nilai yang terkandung dalam upaya pelestarian. Padahal kawasan budaya masa lalu dengan identitas yang jelas merupakan asset yang dapat dikembangkan sebagai kawasan wisata budaya, sehingga akan memberikan multiplier effect semakin pouplernya suatu kawasan dan kota serta memberikan sumber-sumber pendapatan baru bagi pemerintah dan masyarakat dari berbagai aktivitas yang yang menyertainya.
\end{abstract}

Keywords - pelestarian kawasan budaya, pariwisata, conversion, conservation

\section{PENDAHULUAN}

Di masa sekarang ini banyak peninggalan arsitektur masa lalu yang terbengkalai, rusak dimakan zaman bahkan kadang sengaja dihancurkan untuk berbagai kepentingan. Sementara, kehidupan kita di masa kini tak dapat dilepaskan begitu saja dari sejarah masa lalu. Kawasan dengan kumpulan bangunan-bangunan berarsitektur khas sebenarnya dapat menjadi suatu catatan sejarah atas perkembangan suatu masyarakat, budaya, dan perkembangan suatu kotaan.

\section{PEMBAHASAN}

1. Arsitektur dan Pelestarian Kawasan

1.1. Manfaat Upaya Pelestarian dan Konservasi Bangunan Kuno 
Dalam kaitannya dengan mengembangkan gerakan tersebut, Budihardjo (1993) menjelaskan bahwa tujuan dan manfaat dari pelestarian dan konservasi bangunan kuno, pelestarian dan konservasi bangunan kuno adalah sebagai berikut:

- Lingkungan dan Bangunan kuno dengan ragam arsitekturnya yang khas merupakan asset yang sangat berharga dalam bidang pariwisata yang saat ini sedang digalakkan.

- Peninggalan karya arsitektur, baik yang tradisional maupun peninggalan kolonial merupakan rekaman sejarah dalam bentuk visual yang menyiratkan kesinambungan perikehidupan masyarakat dari waktu ke waktu. Peninggalan tersebut menjadi bukti sejarah bagi anak cucu.

- Pada masa-masa yang penuh perubahan secara cepat, lingkungan dan bangunan kuno merupakan suasana tersendiri yang unik, segar, akrab, dapat menjadi tengeran (identitas) untuk orientasi.

- Generasi mendatang membutuhkan rasa aman dan kebanggaan, yang akan diperoleh melalui peluang untuk melihat, menyentuh dan merasakan buktibukti sejarah serta kekayaan budaya nenek moyangnya.

- Dengan dilestarikannya bangunan kuno bersejarah di segenap tempat, khasanah wajah lingkungan akan bertambah kaya.

- Keberhasilan perencanaan dan perancangan lingkungan binaan di masa lampau, akan merupakan bekal dan pelajaran berharga bagi kegiatan serupa di masa depan.

\subsection{Tolok Ukur Dalam Upaya Pelestarian}

Dalam melakukan kajian mengenai konservasi bangunan kuno, terdapat dua pokok pikiran yang perlu diperhatikan, yaitu mengenai (1) batasan istilah dalam konservasi, serta batasan-batasan tertentu yang menjadi (2) kriteria dalam konservasi. Sesuai kesepakatan internasional yang telah dirumuskan dalam piagam BURRA, Budihardjo (1993, p. II-1) menjelaskan bahwa konservasi merupakan istilah payung yang melingkupi seluruh kegiatan konservasi, yang dijelaskan sebagai berikut:

(1) Konservasi; adalah segenap proses pengelolaan suatu tempat agar makna kultural yang dikandungnya terpelihara dengan baik. Konservasi dapat meliputi seluruh kegiatan pemeliharaan dan sesuai dengan situasi dan kondisi setempat serta dapat pula mencakup Preservasi, Restorasi, Rekonstruksi, Adaptasi dan Revitalisasi.

(2) Preservasi; pelestarian suatu tempat persis seperti keadaan aslinya tanpa suatu perubahan termasuk upaya pencegah kehancuran.

(3) Restorasi/Rehabilitasi; pengembalian suatu tempat ke keadaan semula dengan menghilangkan tambahan-tambahan dan pemasangan komponen semula tanpa menggunakan bahan baru.

(4) Rekonstruksi; pengembalian suatu tempat semirip mungkin dgn keadaan semula dgn menggunakan bahan lama ataupun bahan baru.

(5) Adaptasi/Revitalisasi; merubah suatu tempat agar dapat digunakan untuk fungsi yang lebih sesuai. Yang dimaksudkan dengan fungsi yang lebih sesuai adalah kegunaan yang tdk menuntut perubahan drastis atau hanya memerlukan sedikit dampak minimal.

Manfaat Upaya Pelestarian dan Ko 
(6) Demolisi; adalah penghancuran atau perombakan suatu bangunan yang telah rusak atau membahayakan.

Kemudian, dalam kerangka konservasi ini, terdapat sejumlah tolok ukur atau kriteria yang menjadi dasar guna mengetahui bagian/wilayah kota yang mana atau bangunan mana yang perlu dilindungi dan dilestarikan, yang dilihat dari beberapa segi, yaitu (Budihardjo, 1993, p. II-3):

(1) Estetika; bangunan-banguna atau bagian dari kota yang dilestarikan karena mewakili prestasi khusus dalam suatu gaya ttt. Krn pertimbangan dari keputusan yang diambil berbeda-beda, sehingga cukup sulit untuk membiuktikan suatu bangunan lebih penting dari lainnya. Tolok ukur ini dikaitkan dgn nilai estetika dan arsitektonis yang tinggi dalam bentuk, struktur, tata ruang dan ornamennya.

(2) Kejamakan; bangunan-bangunan atau bagian dari kota yang dilestarikan karena mewakili satu kelas atau jenis khusus bangunan yang cukup berperan. Jadi tolok ukur kejamakan ditekankan pada seberapa jauh karya arsitektur tersebut mewakili suatu ragam atau jenis khusus yang spesifik.

(3) Kelangkaan; bangunan yang hanya satu dari jenisnya, atau merupakan contoh terakhir yang masih ada. Jadi termasuk karya yang sangat langka atau bahkan satu-satunya di dunia, tidak dimiliki oleh daerah lain.

(4) Peranan Sejarah; bangunan-bangunan dan lingkungan perkotaan yang telah merupakan lokasilokasi bagi peristiwa-peristiwa sejarah yang penting untuk dilestarikan sebagai ikatan simbolis antara peristiwa terdahulu dan sekarang. Misalnya bangunan tempat Belanda menyerah kepada tentara Indonesia.

(5) Memperkuat Kawasan di Dekatnya; bangunanbangunan dan bagian kota yang karena investasi di dalamnya, akan mempengaruhi kawasan-kawasan di dekatnya, atau kehadirannya sangat bermakna untuk meningkatkan kualitas dan citra lingkungan sekitarnya.

(6) Keistimewaan; bangunan-bangunan ruang yang dilindungi karena memiliki keistimewaan, misalnya yang terpanjang, tertinggi, tertua, terbesar, yang pertama, dan sebagainya.

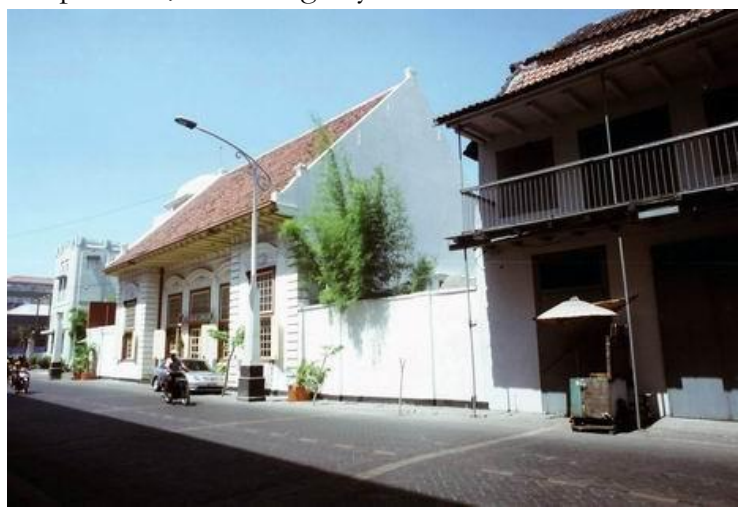

Gambar 1. Perkembangan Positif di Kawasan Kota Semarang. Ex Gedung Pengadilan Yang Telah Alih Fungsi Menjadi Rumah Makan.

\subsection{Keunikan Arsitektur Setempat Sebagai Pembangkit Pariwisata Budaya}

Pada dasarnya tujuan orang mendatangi suatu tempat yang memiliki keunikan tersendiri tidak melulu karena kepentingan pariwisata. Orang yang datang ke kota 
Pekalongan belum tentu karena ingin menikmati keindahan batiknya, tetapi mungkin karena ia adalah seorang pedagang batik. Dalam hal penyusunan paper ini khususnya pada aspek keunikan arsitektur, penulis lebih cenderung melihat aspek arsitektur sebagai aset yang sangat besar manfaatnya guna menggerakkan kedatangan orang ke lokasi atau kota tertentu dalam kerangka pariwisata. Keunikan arsitektur bisa berupa kumpulan rumah-rumah tradisional yang unik, istana atau keraton raja-raja zaman lampau, rumah-rumah kerabat dekat raja, dan sebagainya. Keunikan arsitektur bisa juga berupa lingkungan dengan gaya maupun suasana yang jarang didapati atau bahkan tidak didapati di tempat lain, misalnya lingkungan pecinan, lingkungan peninggalan kolonial, hingga lingkungan kampung di perkotaan.

Dalam hubungannya dengan pariwisata, apapun tipe wisatawannya, kedatangan mereka tidak lain disebabkan karena adanya keinginan untuk menikmati sesuatu keunikan tersendiri yang terdapat di tempat yang didatangi. Keunikan tersendiri ini sifatnya intangible, sehingga sukar untuk diukur, namun dapat dirasakan. Rumah, bangunan, lingkungan, hingga benda-benda yang berada di suatu lokasi yang sifatya tangible-pun harus mampu memberikan nuansa intagible pada wisatawan yang datang. Hal ini penting karena pariwisata adalah produk jasa yang hanya menawarkan janji, dan janji adalah sesuatu yang harus ditepati. Pariwisata merupakan aktivitas yang memiliki keterkaitan yang dengan berbagai sistem yang dapat memberikan multiplier effect memutar roda ekonomi setempat melalui pembelanjaan yang dilakukan oleh para wisatawan yang datang (Pitana, 2005). Tujuan wisata merupakan tempat-tempat yang memiliki batasan tertentu, baik yang berupa batasan fisik, politik, atau batasan yang dibuat untuk kepentingan pemasaran (Kotler, Bowen \& Makens, 1999: 648). Perlu diingat disini, dalam hubungannya dengan bidang pemasaran, khususnya pemasaran jasa, wisatawan hanya mendapatkan janji sebelum peristiwa/kegiatan tersebut dialaminya. Apabila kondisi sesungguhnya yang dirasakan oleh wisatawan terasa lebih rendah kualitasnya dibanding dengan yang dijanjikan, maka wisatawan akan kecewa. Akibatnya promosi buruk yang akan disebarkannya dari mulut ke mulut. Namun apabila kondisi sesungguhnya yang dirasakan lebih baik daripada yang dijanjikan, wisatawan akan merasa puas dan dengan sendirinya akan menjadi sarana promosi yang baik dari mulut ke mulut.

Namun suasana ruang yang telah dibentuk oleh arsitektur tidak akan ada artinya apabila ruang tersebut dirasa mati. Dengan demikian harus diciptakan kondisikondisi lain guna menghidupkan suasana. Disinilah perlu adanya penerapan yang bijaksana pada konsep diferensiasi produk, baik itu pada aspek pemanfaatan nuansa arsitektur maupun produk-produk lainnya yang menyertai keberadaan tempat tersebut.

Diferensiasi produk sebagai unsur penarik perhatian dapat meliputi berbagai aspek. Karena pada umumnya aspek utama yang ditawarkan dalam pariwisata adalah janji akan suasana, maka arsitektur bisa memperoleh porsi yang cukup besar dalam menciptakan suasana ruang di suatu kota atau lokasi tertentu dari kota yang 
bisa dijanjikan untuk dinikmati oleh wisatawan. Dari studi singkat di atas, tampaknya terdapat hubungan timbal balik antara suasana khas yang ditunjang oleh keunikan arsitektur dengan kepentingan wisata. Daerah-daerah tujuan dengan menu utama keistimewaan citra lokal/setempat, umumnya menarik minat wisatawan untuk datang, sehingga memberikan multiplier efect yang menggerakkan ekonomi setempat.

\subsection{Profil Wisatawan dan Harapan Mereka}

Faktor-faktor segi pendorong dilakukannya perjalanan wisata, pada dasarnya seorang dimotivasi oleh faktorfaktor: (a) motivasi yang bersifat fisik atau psikologis, seperti relaksasi, kesehatan, kenyamanan, berpartisipasi dalam kegiatan olah raga, bersantai, (b) motivasi budaya, yaitu keinginan untuk mengetahui budaya, adat, dan kesenian daerah lainnya. Termasuk juga ketertarikan akan berbagai objek tinggalan budaya, (c) motivasi sosial, seperti mengunjungi teman dan keluarga, menemui mitra kerja, melakukan hal-hal yang dianggap mendatangkan gengsi, melakukan ziarah, pelarian dari situasi-situasi yang membosankan, (d) motivasi karena fantasi, yaitu adanya fantasi bahwa di daerah lain seseorang akan bisa lepas dari rutinitas keseharian yang menjemukan dan memberikan memberikan kepuasan psikologis (Pitana \& Gayatri, 2005). Selain itu, adanya keinginan untuk melihat sesuatu yang baru, mempelajari orang lain dan/atau daerah lain, atau mengetahui kebudayaan lain juga dapat menjadi pendorong yang utama di dalam pariwisata (Pitana dan Gayatri, 2005: 37). Dari beberapa penjelasan di atas, dapat dilihat, bahwa motivasi budaya dan adanya tendensi untuk berinteraksi langsung dengan masyarakat dan budaya setempat merupakan potensi yang dapat digali dari seseorang untuk melakukan perjalanan ke suatu tempat.

Dalam hubungannya dengan bidang kearsitekturan, pada hakekatnya, suatu karya arsitektur adalah upaya manusia menciptakan lingkungan untuk menampung kebutuhan manusia bertempat tinggal, berusaha, atau bersosial budaya (Rahmadi BS, 1997). Lebih lanjut dikatakan bahwa jikalau dikatakan arsitektur merupakan buah budaya dan kebudayaan, sebenarnya kita menjadi sadar bahwa dalam pengertian ini arsitektur bukanlah upaya manusia dan masyarakat untuk mengungkapkan kebudayaan lewat bangunan yang diciptakannya. Dalam pengertian itu arsitektur adalah sepenubnya konsekuensi logis dari kebudayaan. Bila sebuab pohon pisang telah cukup umur muncullah buah pisangnya, demikian pula pengertian dari dalam konteks kebudayaan itu (Prijotomo, 1988: 33). Dari sini terlihat bahwa hasil karya arsitektur yang berupa ruang, merupakan tempat atau wadah bagi kehidupan dan interaksi bagi masyarakat. Di dalam arsitektur, terdapat identitas, yang oleh Budihardjo (1997: 34) dijelaskan sebagai target yang selalu berubah, sejalan dengan perubahan waktu dan masyarakatnya, sebagai suatu proses kultural yang tidak bisa difabrikasikan, apalagi secara massal. Hal ini menunjukkan bahwa dari aspek arsitektur, setiap daerah atau lokasi tetentu memiliki identitasnya masing-masing. Pesona arsitektur, memiliki potensi mendorong seseorang untuk datang, melihat, merasakan, berinteraksi, serta mempelajarinya. Suasana yang khas dan berbeda dengan tempat asal, juga akan mendorong seseorang untuk mendatangi lokasi tertentu untuk melepaskan diri dari rutinitas 
kesehariannya. Pesona yang ditimbulkan oleh lingkungan dan/atau ruang dengan arsitektur tertentu, dapat menjadi suatu pengalaman yang mengesankan bagi seseorang yang hadir dan berinteraksi di dalamnya.

Salah satu contoh bagian kota yang memiliki identitas karena keunikan arsitektur dan diferensiasi produknya adalah kawasan Jalan Malioboro Yogyakarta. Lingkungan arsitekturnya yang berada di selasar pertokoan sebenarnya tidak terlalu istimewa dan kurang mencerminkan gaya jawa, namun pengelolaan lingkungan dan pengolahan fisik dengan penempatan street furniture, desain jalur pejalan kaki, adanya delman tradisional jawa, pengaturan waktu dan penempatan barang-barang dagangan, perbedaan produk dagangan pada siang dan malam hari, tersedianya lokasi homestay di rumah masyarakat setempat di balik dinding pertokoan yang dapat dicapai langsung dengan berjalan kaki, serta bahasa jawa yang dipergunakan oleh mayoritas warga (penduduk dan pedagang) setempat telah menjadi diferensiasi produk yang sangat istimewa. Begitu istimewanya kemasan diferensiasi produk ini sehingga arsitektur bangunan toko-toko utama di sepanjang jalan tidak lagi dirasa sebagai deretan pertokoan, namun seakan-akan menjadi semacam Yogya kecil di dalam kota Yogyakarya.

Apabila dilakukan perbandingan, kondisi di malioboro sangat akomodatif bagi wisatawan baik dari tipe organized mass tourists hingga backpacer, sebaliknya kota lama semarang belum menunjang untuk segala tipe wisatawan, dan tampaknya masih terasa sebagai benda asing bagi wisatawan tipe explorers dan drifters/bacpackers yang cenderung berinteraksi langsung dengan masyarakat setempat, karena memang di lokasi tersebut nyaris tidak ada masyarakatnya. Lebih-lebih pada malam hari, kawasan kota lama benarbenar menjadi kota mati tanpa kegiatan apa-apa. Sekedar usulan, tahap pertama dengan menyulap sebagian bangunan di kota lama semarang di tepi sungai menjadi fungsi hotel, fungsi perbelanjaan, fungsi apartemen (dengan catatan tanpa merusak citra arsitekturnya) akan dapat memperpanjang jam hidup kota lama. Selanjutnya dapat ditumbuhkan wisata makan malam hari mulai dari kelas bawah hingga kelas atas. Apabila sungai samping kota lama dapat dihidupkan kembali sebagai sarana transportasi, rasanya bukan hanya wisatawan saja yang lemudian akan menikmatinya, namun sebagian warga semarang yang memiliki kepentingan bekerja, berdagang, berbelanja, dan sebagainya di kawasan pasar johar dapat memanfaatkannya sebagai sarana transportasi. Penulis berpendapat apabila usulan ini dapat dikembangkan, hasilnya dapat menjadi multiplier effect bagi pertumbuhan ekonomi di lingkungan kota lama, yang pada akhirya kepentingan bisnispun akan kembali melihat kota lama sebagai lokasi yang representatif untuk menjalankan usaha, sehingga kota lama menjadi hidup kembali.

\section{Perkembangan Negatif Yang Terjadi}

Dalam beberapa kasus, kawasan dengan potensi lokal dan menjadi cikal bakal suatu kota telah mengalami penggerusan. Proses penggerusan ini terlihat dari tumbuhnya bangunan baru yang secara arsitektur indah dan modern, manun keindahan dan kemodernannya 
jusrtu berpotensi 'merusak' suasana yang telah ada sebelumnya. Sebagai contohnya, di Semarang, di kawasan Jalan Pemuda. Di gerbang Jalan Pemuda yang sekaligus menjadi poros menuju Kota Lama Semarang, terdapat bangunan Lawang Sewu yang memiliki keistimewaan pada penampilan arsitekturnya. Keunikan arsitektur Lawang sewu membangun image yang kuat bagi Semarang sebagai kota Belanda. Tidak jauh dari Lawang Sewu, berdiri sebuh bangunan mall, dengan logo perusahaan retail yang cukup mencolok. Bagi sebagian masyarakat awam, tentu saja mall baru akan dikatakan sebagai sesuatu yang hebat, namun dari sudut pandang pelestarian budaya melalui situs-situs yang masih ada, tumbuhnya bangunan berarsitektur 'instant' ini dapat menghasilkan 'suasana yang negatif'

Kondisi berbeda ditemui di kota lama Semarang. Kota Lama Semarang ibaratnya The Little Netherland, dibangun di tepi sungai, merupakan bekas pusat kota pada zaman Belanda dengan Arsitektur Indische (hasil akulturasi arsitektur barat yang dibawa oleh bangsa belanda dengan penyesuaian dengan lingkungan setempat). Hingga ini masih dapat dirasakan sisa-sisa kekuatannya sebagai bekas pusat kota bisnis di lokasi kota lama, namun yang masih bisa dinikmati dan menjadi ciri tempat tersebut hanya keindahan arsitekturnya saja. Kawasan kota lama semarang telah menjadi area yang dilindungi, namun kegiatan di tempat tersebut masih terasa mati, khususnya bagi perkembangan pariwisata. Kepentingan bisnis di zaman ini yang telah berubah menginginkan lokasi usaha di tempat lain yang dirasa lebih representatif, akibatnya kota lama semarang ditinggalkan dan menjadi bagian kota yang mati. Melihat kasus ini, penulis berpendapat revitalisasi kota lama semarang tidak bisa hanya menitik beratkan pada pembenahan fisik saja, namun harus bisa memasukkan aktivitas baru yang lebih cocok dengan perubahan zaman di lokasi tersebut. Tentu saja arah pengembangan lokasi ini tidak dapat disamakan dengan arah pengembangan malioboro yang secara alamiah dikelilingi oleh masyarakat lokal, sehingga dari segi pariwisata menjadi sangat akomodatif bagi segala tipe dan motivasi wisatawan.

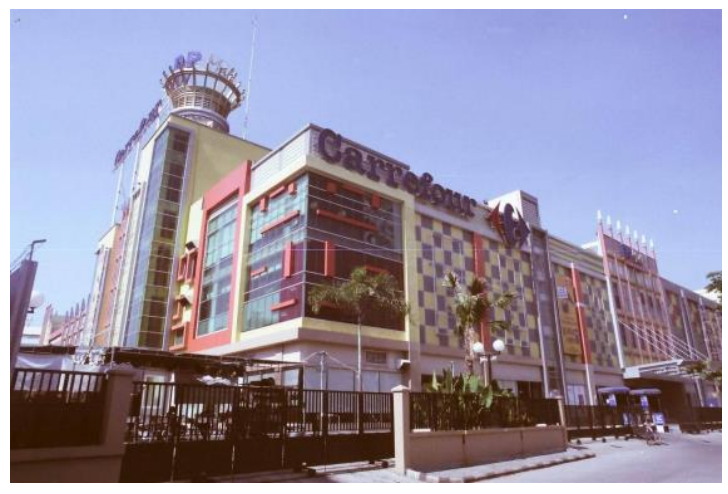

Gambar 2. Mall Masa Kini di Dekat Gedung Lawang Sewu Semarang

Walau belum dilakukan studi yang mendalam, namun dari studi singkat yang sempat dilakukan penulis, dari beberapa lokasi dapat dirasakan adanya hubungan timbal balik antara revitalisasi lingkungan arsitektur yang diiringi dengan diferensiasi produk wisata dengan perhatian masyarakat pada suatu tempat tertentu. Tempat yang dimaksudkan disini adalah yang bersifat 
public space, dapat dinikmati oleh segala lapisan masyarakat, dan bisa berarti suatu kawasan atau lokasi, beberapa kawasan dan lokasi yang berada di wilayah tertentu dan memiliki saling keterhubungan yang unik. Kawasan atau lokasi ini mungkin saja merupakan bagian dari kota, atau bahkan keseluruhan kota. Namun tidak tertutup kemungkinan yang dimaksudkan dengan kota ini hanya berupa kota kecamatan yang kecil tetapi memiliki keistimewaan tertentu. Berapapun skala kota tersebut atau dimanapun lokasi tersebut, sepanjang tempat tersebut memiliki keistimewaan akan selalu menarik perhatian orang lain yang berada di luar.

Dalam pemasaran, keistimewaan yang menjadi daya tarik dan membedakan antara suatu produk dengan produk lainnya disebut sebagai diferensiasi. Diferensiasi yang baik akan mampu menempatkan positioning yang baik di benak orang lain yang akan dijadikan sebagai target market. Hal ini penting, karena dengan tercapainya positioning yang baik dengan sendirinya akan mendorong orang untuk mempertimbangkan memilih produk tertentu. Apabila konsep pemikiran ini dapat diaplikasikan dengan bijaksana ke dalam rencana pengembangan suatu kota, bagian kota, lokasi tertentu dalam kota, maka dapat dipastikan orang yang berada di luar akan tertarik dengan lokasi tersebut, dan mendorong mereka untuk melakukan perjalanan dan datang ke tempat tersebut.

\section{KESIMPULAN}

Melalui proses-proses tersebut yang berlangsung dalam jangka panjang, citra kawasan dengan keunikan arsitekturnya akan dapat dikembalikan mendekati citranya aslinya. Berlangsungnya proses tersebut membutuhkan penyesuaian atau adaptasi antara aktivitas-aktivitas masa kini yang terus berkembang terhadap wadah fisiknya yang berupa kawasan dengan gambaran masa lalu. Berkaitan dengan adaptasi tersebut, Prijotomo (1988: 24) menjelaskan bahwa dalam kerangkea tinjanan atas tradisi, sikap 'mengadilibungkan' tradisi tidak boleh diartikan dengan memupusakakan, memisterikan, apalagi dipantangkan untuk dimodifikasi dan diadaptasi; hanya dengan sikap ini maka tradisi akan berkesinambungan.

Adanya perbedaan kepentingan antara pelestarian dan perkembangan zaman merupakan tantangan bagi masyarakat, para pakar, dan pengambil keputusan untuk secara arif bijaksana mengelola perubahan yang terjadi. Masyarakat dan pengelola setempat, harus memiliki alasan yang kuat untuk mempertahankan bukan hanya adat dan tradisi semata, namun juga memelihara citra dan pesona arsitektur lokal sebagai media penarik wisatawan. Situasi tersebut menunjukkan adanya suatu hubungan timbal balik antara pelestarian dan perkembangan zaman. Semakin kuat nuansa yang dapat dirasakan, akan semakin tinggi pula minat wisatawan mendatangi lokasi tersebut.

Bagi pengambil kebijakan, perlu kiranya untuk menjaga keunikan Arsitektur sebagai product differentiation dalam rangka membangkitkan pariwisata di kawasan budaya. Hal tersebut penting karena kadang-kadang kepentingan pariwisata akan 'memaksa' ekspresi kebudayaan lokal untuk dimodifikasi, agar sesuai dengan kebutuban pariwisata dan agar dapat 'dijual' kepada 
wisatawan (Pitana dan Gayatri, 2005). Sementara di lain pihak, kesenian, kerajinan, dan berbagai aspek kebudayaan lokal bisa mengalami revitalisasi akibat kedatangan pariwisata (De Kadt, 1997., dalam Pitana dan Gayatri, 2005: 137). Merupakan kewajiban bagi masyarakat untuk senantiasa mendorong pemerintah agar menetapkan Undangundang yang ketat dalam masalah pelestarian.

\section{REFERENSI}

Alport, Gordon W. Attitudes. A Handbook of Social Psychology. Worcester: Clark University Press, 1935.

Aaker, D.A, Kumar, V., \& Day, G. S. Marketing Research. New York: John Wiley \& Sons, 1998.

Ajzen, Icek. The Theory of Planned Behavior. Organizational Behavior and Human Decision Process, (50), 1991: 179-211.

Budihardjo, Eko. Inventarisasi Bangunan Kuno. 1993.Heuken, Adolf., \& Grace Pamungkas. Menteng Kota Taman Pertama Di Indonesia. Jakarta: Cipta Loka Caraka, 2001.

Morrison, Alastair M. Hospitality and Travel Marketing. New York: Delmar Publishers, 1996.

Priatmodjo, Danang. "Melestarikan Bangunan Kuno: Gitu aja kok repot". Majalah Jakarta dan Arsitektur, Vol.7, Mei - Juni 2000.

Sadana, Agus Surya. Pengembangan Restoran Tempo Doeloe 'Kunstkring' Sebagai Upaya Membangun Kembali Kemandirian Pengelolaan Gedung Ex-Kantor Imigrasi Jakarta Pusat. Pemenang ke-III dalam Sayembara Gagasan Fungsi Dan Pengelolaan Gedung Ex Kantor Imigrasi Jakarta Pusat, Diselenggarakan oleh Dinas Kebudayaan Dan Permuseuman DKI Jakarta, dan Lembaga WALIBATU Jakarta, 2003

Sumalyo, Yulianto. Arsitektur Kolonial Belanda Di Indonesia. Yogyakarta: Gadjah Mada University Press, 1993.

Wiryomartono, A. Bagoes P. Seni Bangunan Dan Seni Binakota Di Indonesia. Jakarta: Gramedia Pustaka Utama, 1995 